\title{
Chapter 24 \\ Diaspora Policies, Consular Services and Social Protection for Romanian Citizens Abroad
}

\author{
Felicia Nica and Madalina Moraru
}

\subsection{Introduction}

This chapter aims to bring to the foreground recent developments regarding the situation of the Romanian diaspora. The first part of the chapter provides a taxonomy of the main public authorities interacting with the Romanian diaspora and of the key social policies affecting it. The second part of the chapter proceeds with an overview of how the institutional and policy setting on Romanian diaspora is working in concrete sectors. It will analyse in detail the policies, programmes and services offered by Romanian authorities to respond to the social protection needs of nationals abroad across five policy areas: unemployment, health care, pensions, family benefits, and guaranteed minimum resources. As we will argue, Romania's engagement with its citizens abroad has concentrated on the preservation and development of the Romanian identity abroad, strengthening Romanian associations abroad, supporting the integration process and protecting the rights of Romanians abroad (National Strategy for Romanians Abroad 2017-2020¹). In addition, since 2018, diaspora policies have also targeted the return of Romanians by offering them grants

\footnotetext{
${ }^{1}$ Available here: http://www.mprp.gov.ro/web/strategia-privind-relatia-cu-romanii-de-pretutindeni-2/. Accessed March 2019.

F. Nica $(\triangle)$

National Expert Asylum Information Database (AIDA), European Council on Refugees and Exiles, Brussels, Belgium

M. Moraru $(\bowtie)$

Masaryk University, Brno, Czech Republic

Centre for Judicial Cooperation of the European University Institute, Florence, Italy e-mail: Madalina.Moraru@eui.eu; madalina_bianca.moraru@law.muni.cz
} 
for the implementation of projects or actions. ${ }^{2}$ As we will show, policies in the area of social protection are, however, much more limited.

\subsection{Diaspora Policy Infrastructure and Key Policies}

\subsubsection{The Romanian Diaspora and Its Relations with the Homeland}

The Romanian emigration has been described as "the biggest, most complex and dynamic migration to Western Europe" (Anghel et al. 2016). After the fall of communism in 1989, Romania encountered several emigration phases (Sandu 2010). At the beginning of the 1990 s, the country registered a mass departure of citizens of German origins. Between 1996 and 2001, the migration flow decreased and the main destination countries in this period were the United States (US) and Canada (Sandu 2010). Another major emigration wave started once Romanians obtained the right to travel without a visa within the European Union (EU), subsequent to Romania's accession to the EU. The Romanian diaspora experienced one of the fastest annual growths (7.3\% per annum), following the Syrian diaspora with $13.1 \%$ yearly growth rate, between 2000 and $2015 .{ }^{3}$ Eurostat $(2018)^{4}$ noted that of all EU countries, Romania was the country with the highest numbers of emigrants in the EU in 2017 (87\% of all migrants). Italy and Spain represented the main destinations for Romanians between 2000 and 2010.5 In 2017, while these two countries remained the top two destinations, Germany, the United Kingdom (UK) and France were also important host countries for Romanians abroad. ${ }^{6}$ The Romanian diaspora has a significant presence not only in the EU, but also around the globe, in particular in the US and Canada.

\footnotetext{
${ }^{2}$ Law no. 321/2006 on allocation of grants for programs, projects or actions supporting Romanians' activity abroad and organizations representing them, as well as the allocation and use of the dedicated budget of the Ministry for Romanians Abroad for this activity, published in the Official Journal No. 586 of 10 July 2018.

${ }^{3}$ United Nations (2015). International Migration Report 2015 Highlights, 19. https://bit. ly/1RQIond. Accessed March 2019

${ }^{4}$ Eurostat (2018). Migration and migrant population statistics, 3. https://bit.ly/2DuBGjq. Accessed March 2019.

${ }^{5}$ In Italy, they are approx. 1,150,000 Romanians officially registered, while in Spain - over 900,000 Romanian citizens. See: Ministerul Muncii, Familiei, Protecției Sociale și Persoanelor Vârstnice (2017). National Report for the Third Review and Appraisal Cycle of the Implementation of the MIPAA/RIS Romania (2012-2016). https://www.unece.org/fileadmin/DAM/pau/age/country_ rpts/2017/ROU_report.pdf. Accessed March 2019.

${ }^{6}$ Around 500,000 in Germany, around 330,000 in the UK and around 110,000 in France (Vintila and Soare 2018).
} 
According to an OECD report, ${ }^{7}$ in 2017 , the number of Romanian emigrants reached 3.58 million, which represented $18.2 \%$ of the population. The report also highlighted that Romania not only registered the highest number of emigrants, but also the highest number of high-skilled emigration into the Group of Twenty (G20) countries (about 492,000 persons in 2010/11). With the exception of the economic crisis period (2008-2013), the number of Romanian emigrants continued to grow until 2018, when the World Bank reported that around three to five millions of Romanians lived and worked abroad. ${ }^{8}$

The growing Romanian diaspora and its potential influence on home country politics has triggered a fast development of the diaspora engaging institutions in Romania, but also a politicisation of diaspora issues. New diaspora institutions emerged, while already existent institutions were adapted to better respond to the needs of the growing number of non-resident nationals. This resulted in a diaspora infrastructure made up of four types of institutions, depending on the governmental level where they were established. ${ }^{9}$

\subsubsection{Diaspora Infrastructure}

The Romanian Ministry of Foreign Affairs coordinates an extensive number of external missions (151), which implement the foreign policy guidelines set out centrally at the ministerial level. ${ }^{10}$ The Ministry also provides consular services to Romanians abroad through its consular posts. The number of consular representations varies from country to country, with more consulates in Spain (seven) and Italy (six), i.e. the main destination countries. In general, there is a consular section within the diplomatic mission in the respective country and additional consular posts. ${ }^{11}$ The Romanian law prescribes the possibility to provide consular services by the consular officers outside the headquarters of a diplomatic mission or consular

\footnotetext{
${ }^{7}$ OECD. G20 Global Displacement and Migration Trends Report 2017. https://bit.ly/2X6Yrmz. Accessed March 2019.

${ }^{8}$ The World Bank (2018, June) Romania Systematic Country Diagnostic BACKGROUND NOTE Migration, 7. https://bit.ly/2AapDta. Accessed March 2019.

${ }^{9}$ At the ministerial level: Ministry for Romanians Abroad; national: Department for the Relation with Romanians Abroad, part of the Presidential Administration; part of a consular network: consulates; quasi-governmental: Eudoxiu Hurmuzachi" Institute for Romanians Abroad and the Congress of Romanians Everywhere. This classification follows the general diaspora institution infrastructure described in: International Organisation for Migration (2013). Handbook on Diaspora, p. 72

${ }^{10}$ The full list of permanent external missions is available in Romanian at: http://www.mae.ro/ romanian-missions [accessed March 2019]. This list does not include the honorary consulates.

${ }^{11}$ For example, in Italy there are six consulates and a Consular Section within the Romanian Embassy in Rome, while in Hungary there are two consulates and a Consular Section within the Romanian Embassy in Budapest [last checked March 2019].
} 
post, which in practice takes the form of mobile consulates. ${ }^{12}$ Mobile consulates were created to provide consular services to elderly or sick persons who cannot travel long-distances, persons with less material possibilities or those who do not have the opportunity to travel to the headquarters of diplomatic missions. Mobile consulates provide the same consular services as the Consular Section. However, they cannot substitute the functioning of the Consular Section, as they do not have the capacity to receive and solve all consular services requests from a local community. ${ }^{13}$

Furthermore, to eliminate bureaucratic and geographical barriers to consular services, the Ministry of Foreign Affairs also created an online consular counter/office, where Romanians may lodge requests and interact online with the consulate employees. ${ }^{14}$

According to the Romanian Consular Regulation, "Romania may establish, on a reciprocal basis, honorary consular offices on the territory of other states and may appoint honorary consuls who can be nationals of or citizens of other states and function according to international law, rules, principles and practice". ${ }^{15}$ The Minister of Foreign Affairs has to approve the establishment of honorary consular offices and the appointment of the heads of such offices..$^{16}$ Concerning their attributions, the honorary consuls are carrying out consular duties that do not involve the exercise of state authority and thus cannot provide services relating to citizenship, marital status, notarial acts, passport issuance or granting visas. ${ }^{17}$

10 years after Romania's accession to the EU, a Ministry with full standing was created to address the needs of the Romanian diaspora. The Ministry for Romanians Abroad (Ministerul pentru românii de pretutindeni, MpRP) was established based on the Government Emergency Ordinance No. 1 of 2017 for establishing measures in the field of central public administration and for amending and completing some normative acts. Before that, the needs of nationals abroad were under the responsibility of the Council for the Problems of Romanians Elsewhere (Consiliul Românilor de Pretutindeni, established in 1995) and a state sub-secretary for Romanians abroad, created in 1998 (Moraru 2010). From 1999 until 2017, diaspora issues were under the responsibility of a dedicated structure within the Ministry of Foreign Affairs - the Department of Policies for Relations with Romanians Abroad

\footnotetext{
${ }^{12}$ Article 1(9) of the Order No. 400/2016 on the technical modalities for the provision of consular services and the control of the fees levied from these services at the diplomatic missions and consular offices of Romania abroad.

${ }^{13}$ Romanian Embassy in the US, Mobile Consulates, available at: https://bit.ly/2IEIsEn [accessed March 2019].

${ }^{14}$ See: https://bit.ly/2FwYBvy [accessed March 2019].

${ }^{15}$ Article 24 (1) of the Governmental Decision No.760 of 1999 on the approval of the Consular Regulation, as amended by Governmental Decision No. 1085 from 28th October 2010.

${ }^{16}$ Article 24 (2) of Decision No.760 of 1999 on the approval of the Consular Regulation, as amended.

${ }^{17}$ Article 25 (1) and (2) of Decision No.760 of 1999 on the approval of the Consular Regulation, as amended.
} 
(DPRRP). It is noteworthy that these institutional developments actually occurred prior to the biggest emigration wave during mid-late 2000s.

The Eudoxiu Hurmuzachi Institute for Romanians Abroad also used to be subordinated to the Ministry of Foreign Affairs. Currently, the Institute is a public institution of national interest, having legal personality, subordinated to the Ministry of Romanians Everywhere. ${ }^{18}$ The Institute aims to support education abroad in Romanian language and, more broadly, the promotion of Romanian language, culture and traditions among the Romanian communities.

The Presidential Administration also has a specialized structure focusing on the Romanian diaspora - the Department for the Relation with Romanians Abroad (AP-DpRRAG). Led by a state counsellor, this Department aims to ensure the collaboration between Romanian institutions and representatives of Romanians abroad, elaborate specific documents and organize activities dedicated to Romanian communities, and represent the President at various events. To accomplish these tasks, the Department is planning, organising and conducting activities in Romania and abroad, which are attended by the President of Romania and have as a theme the dialogue with Romanians abroad. ${ }^{19}$

The Romanian diaspora is also represented in the Romanian Parliament. However, "these external constituencies were geographically divided and did not take into account the number of Romanian citizens residing in the various countries and regions covered" (Vintila and Soare 2018). Namely, two Senators and four Deputies are elected to represent the interests of three to five million Romanians living abroad. ${ }^{20}$ One could argue that the interests of the Romanian diaspora are poorly represented in the Parliament when compared to the representation of Romanians living in Romania, which is one deputy for 73,000 nationals and one senator for 168,000 nationals. ${ }^{21}$ The issue of underrepresentation of the Romanian diaspora has also been debated by academics, who suggested that the number of the Members of Parliament (MPs) representing the diaspora could be determined by taking into consideration either the number of non-resident Romanians with voting rights or the number of Romanians who, according to the latest Census, left the country for a long time (Jiglău 2016). In addition to this special representation, both parliamentary chambers have designated commissions for the Romanian diaspora. ${ }^{22}$

\footnotetext{
${ }^{18}$ Decision No. 17/2017 regarding the organization and functioning of the Ministry for Romanians Abroad, as well as for the modification and completion of the Government Decision No. 857/2013 on the organization and operation of the "Eudoxiu Hurmuzachi" Institute for Romanians from around the world.

${ }^{19}$ Presidential Administration, the Department for the Relationship with Romanians Abroad, available at: https://bit.ly/2IHh6gL [accessed March 2019].

${ }^{20}$ This number was cited by the Chamber of Deputies. However, according to the National Strategy for Romanians Abroad 2017-2020, the number of Romanians abroad is currently estimated at almost 10 million - including both Romanians living in diaspora communities and those who live in the historical/traditional communities in neighbouring countries.

${ }^{21}$ Article 5 of the Law No. 208 of 20 July 2015 on the election of the Senate and the Chamber of Deputies, as well as for the organization and functioning of the Permanent Electoral Authority.

${ }^{22}$ See: https://bit.ly/2JzT4pa and https://bit.ly/2GPacK7 [accessed March 2019].
} 
Following the global trend of creating diaspora councils as a source of funding and technical know-how with minimal cost to the government, ${ }^{23}$ Romania established the Congress of Romanians Everywhere and its executive body - the Consultative Council of Romanians Everywhere. ${ }^{24}$ This is the first institution of this kind created in Romania, representing Romanians residing abroad at the national level. The Congress is quite a recent institution, although the obligation of the Parliament to set it up dates back to $2007 .{ }^{25}$ The Congress is made up of delegates of Romanians abroad. ${ }^{26}$ There are several conditions to become a delegate. Firstly, to present a written intention to represent the Romanian community in the residence country, on the delegate's name, accompanied by supporting documents of residency outside Romania. Secondly, to present a list of at least 250 signatures supporting the candidacy from Romanians residing in the foreign country. Thirdly, the candidates must reside in the foreign country and be at least 18 years old. Delegates are chosen by the Technical Secretariat, which was specifically established to organize the Congress and includes one representative from each parliamentary party. ${ }^{27}$ Although the legislation provides that the Congress of Romanians Abroad should be organized annually in Romania or abroad under the aegis of the Romanian Parliament, ${ }^{28}$ its first (and only) meeting took place in 2016 (National Strategy 2017-2020). At the time of writing, ${ }^{29}$ the Congress organisation and functioning were not yet formally approved by the Parliament.

\subsubsection{Key Engagement Policies}

According to Eurostat (2018), in 2017, the number of Romanian emigrants reached 3,58 million, which represented $18.2 \%$ of the Romanian population. Counting the number of Romanians abroad is a complicated task. There is no official register of those residing abroad and it is therefore common practice for Romanians living abroad to maintain a domicile in Romania, while establishing their residence in

\footnotetext{
${ }^{23}$ See International Organisation for Migration (2013). Handbook on Diaspora.

${ }^{24}$ According to Law No. 299/2007, Article 8, "The Congress of Romanians Abroad is convened by the standing bureaux of the Chamber of Deputies and the Senate, in collaboration with M.R.P., and the expenses for the organization and running of the Congress of Romanians Abroad are ensured from the budget of the Chamber of Deputies. (3) On the occasion of its first meeting, the Congress of Romanians Abroad will appoint its governing bodies and will elaborate the rules of operation.

(4) The Congress of Romanians Abroad is a forum for debate and consultation of representatives of Romanians everywhere, persons and / or organizations."

${ }^{25}$ Article 8 of Law No. 299/2007 concerning the support given to Romanians abroad.

${ }^{26}$ Article 3 of the Regulation on the Functioning of the Congress of Romanians Living Abroad.

${ }^{27}$ Article 4(1) Methodology on the organisation of election of delegates to the Congress of Romanians Abroad. This act can be found online http://www.cdep.ro/docs_comisii/diaspora/ metodologie.pdf it was not published in the Official Journal.

${ }^{28}$ Article 8 Law No. 299/2007.

${ }^{29}$ March 2019.
} 
another country (Anghel et al. 2016). One possible advantage of keeping a domicile in Romania while residing abroad is that revenues made outside working contracts will be taxed at a lower rate in Romania to Western European countries of residence. ${ }^{30}$ Nonetheless, the Ministry of Foreign Affairs recommends Romanian citizens living abroad to voluntarily register their presence in the area, at the nearest Romanian consular office, in order to be contacted in emergency situations. Registration is based on free consent. ${ }^{31}$

Over the years, the Romanian Government has developed policies to support the integration of Romanians in foreign countries and encourage their return to Romania. The goals set by Ministry for Romanians Everywhere, established in 2017, therefore explicitly promote the preservation and development of the Romanian identity for citizens living abroad and their integration abroad (National Strategy 2017-2020).

One central policy to engage with citizens abroad consists in awarding grants to associations, foundations, cults, other non-governmental organizations of Romanians abroad, international organizations and other authorized natural or legal persons of public or private law from Romania or abroad, insofar as the nonreimbursable financing is used to run programs, projects or actions in support of Romanians abroad. ${ }^{32}$ The funds may also cover assistance for establishing Romanian organisations and associations abroad. The overall policy objectives of the MpRP are broader than the previous policy agenda pursued by the Ministry of Foreign Affairs for the Romanian diaspora, which, for instance, did not include the explicit encouragement of return. ${ }^{33}$

The priority of the Eudoxiu Hurmuzachi Institute for Romanians Abroad is to support non-resident nationals in preserving their cultural and linguistic identity through: pre-university training for Romanians abroad; research; training for the teachers; summer camps for pupils or/and students and teachers; cultural, artistic, scientific, educational, documentary activities, mainly for young Romanians from communities in the vicinity of Romania. ${ }^{34}$

\footnotetext{
${ }^{30}$ Romania's tax is of approximately $10 \%$ of such revenues (see Fiscal Code), while in other countries, the taxes can go as high as $20 \%$ or $30 \%$ (see for instance, Italy). For more tax data, see the Eures database.

${ }^{31}$ There is also the possibility of having a CRDS passport (electronic passport for Romanians with the domicile abroad): https://www.mae.ro/node/1428 [accessed March 2019].

${ }^{32}$ Article 3 of the Law No. 321/2006.

${ }^{33}$ The three key policies targeting the Romanian diaspora were: "maintaining the cultural and linguistic identity "of Romanians living abroad; promoting the image of Romania by cultivating relations with the elite Romanians, thus promoting them as models; supporting the integration process by supporting the coagulation efforts of the Romanian communities and affirming a positive identity profile, promoting the image of open communities, oriented towards intercultural dialogue." See: Ministry of Foreign Affairs (2014). Report published by the Department of Policies for Relations with Romanians Abroad, http://www.mae.ro/node/26399. Accessed March 2019.

${ }^{34}$ Eudoxiu Hurmuzachi Institute for Romanians Abroad, Mission and Strategy, available at: https:// bit.ly/2JBoJqs [accessed on March 2019].
} 
A considerable role in developing legislative initiatives concerning Romanians abroad is played by the Congress and the Consultative Council of the Romanians Everywhere. The Council provides information, analyses and proposes legislative initiatives for Romanians everywhere, concerning, inter alia, the realisation and application of programs for Romanian communities. These initiatives should be presented to the Romanian Parliament, the Ministry for Romanians Everywhere and other competent governmental institutions with whom they collaborate. ${ }^{35}$ However, the Congress' precise role is yet to be fully clarified. So far, the Congress has been organised only once, and the development of its political intentions and programme have been in a stand-by due to the lack of internal agreement in the Parliament regarding the Congress's working methodology. The potential powerful impact of the Congress on the Romanian diaspora has arguably made it the subject of political interest and dispute, with various political parties aiming to get control over this institution for the purposes of using it as a strategic tool for disseminating their political platforms. ${ }^{36}$

Looking at electoral rights, Romanians living abroad have the right to vote in presidential and European Parliament elections, as well as referendum, held in Romania without fulfilling any additional conditions compared to residents. As for national legislative elections, Romanians living abroad have to register in the electoral register by sending or lodging at the Romanian embassy or consular office a written request accompanied by a copy of the identity document and document proving his/her residence, issued by the authorities of the host country. ${ }^{37}$

With regards to the right to stand as a candidate, only citizens who have the domicile in Romania enjoy this right. ${ }^{38}$ The four Deputies and two Senators representing the diaspora are elected following the same procedure as the rest of the MPs. Namely, during the legislative elections, citizens elect a political party which proposes its own candidates list (closed lists).

Next to electoral rights, various financial contributions are granted by different authorities to Romanians abroad with the aim of encouraging them to return, which is a significant focus of the Romanian authorities' engagement with the diaspora. For instance, the Ministry of Labor and Social Justice is granting financial incentives for repatriation to Romanian workers who have exercised their right to free movement in the EU and the European Economic Area (EEA) for at least

\footnotetext{
${ }^{35}$ Article 4 (1) of the Regulation on the Functioning of the Council of the Romanians Abroad.

${ }^{36}$ See: Prisăcaru, M. (2017). "Noi vrem congres!” - Scrisoare deschisă a Consiliului Românilor de Pretutindeni, https://www.stiripesurse.ro/noi-vrem-congres-scrisoare-deschisa-a-consiliuluiromanilor-de-pretutindeni_1237679.html. Accessed March 2019. See also: USR (2018). Poziția USR pe tema Congresului Românilor de Pretutindeni https://www.usr.ro/2018/01/31/pozitia-usrpe-tema-congresului-romanilor-de-pretutindeni/. Accessed March 2019.

${ }^{37}$ Article 42 of the Law 208/2015 on the election of the Senate and the Chamber of Deputies, as well as for the organization and functioning of the Permanent Electoral Authority, see (Vintila and Soare 2018)

${ }^{38}$ See Article 16(3) Romanian Constitution.
} 
36 months. ${ }^{39}$ The Ministry of European Funds, with the support of MpRP, developed a funding line for Romanian citizens who recently returned from abroad, named Diaspora Start-Up. This program encourages unemployed, inactive or employed Romanians to start a business in Romania, in their field of specialisation. ${ }^{40}$ Lastly, the Ministry of Education and Scientific Research awards scholarships and tuition fees for Romanians with permanent residence abroad for the purpose of supporting undergraduate, graduate, master and doctoral education in Romania. $^{41}$

\subsection{Diaspora Policies and Social Protection in and outside Romania}

When it comes to Romania's involvement in the area of social protection for citizens abroad (see also Burlacu et al. 2020), most activities focus on informing nationals about their social entitlements in the host countries and in Romania. Until January 2018, the Ministry of Public Consultation and Social Dialogue had a separate section on its website with information on employment, social security, pension, residence, health insurance, and other social services in several EU Member States (the UK, Ireland, France, Germany, Spain, Italy, Greece and Cyprus) to nationals already residing abroad or citizens who wish to emigrate. In addition, it also contained useful information for nationals abroad who intend to return to Romania ${ }^{42}$ However, this Ministry was dismantled in January $2018^{43}$ and this specific information was not transferred to the Ministry of Labor.

Additional information is provided by the General Directorate for European Affairs and International Relations within the Ministry of Labor and Social Justice. The Directorate elaborated a comprehensive document with frequently asked

\footnotetext{
${ }^{39}$ See Article $76^{\wedge} 1$ of the Law 76 of 16 January 2002 on the unemployment benefit system and on the stimulation of employment. The only requirement to receive the financial incentive is to return and find a job, there is no need to set up a business.

${ }^{40}$ Ministry of European Funds, 76 million euro for Romanians living in the Diaspora who want to open a business, see http://diaspora-start-up.ro/ [last accessed on November 2018].

${ }^{41}$ Government Decision no. 689/1994 regarding the granting of scholarships, doctorates and specialization, other forms of support for young people of Romanian ethnic origin or for Romanian citizens residing abroad; Law no. 299/2007 regarding the support given to Romanians living abroad. See: https://bit.ly/2paDJIX [accessed March 2019].

${ }^{42}$ Ministry of Public Consultation and Social Dialogue. Developing the institutional capacity to provide public information services to Romanian migrant citizens. https://bit.ly/2HasRiH . Accessed March 2019.

${ }^{43}$ GEO No.1 / 31.01.2018 on the reorganization measures within the central public administration.
} 
questions. This document includes information about the attachés on labor and social problems and about social protection in the host country where there is an attaché. $^{44}$

Beyond the mere provision of information, the Ministry of Labor and Social Justice has developed a network of 11 attachés on labor and social problems based in Romania's diplomatic missions in Spain, France, the UK, Germany, Hungary, Italy, the Netherlands, Sweden and the United Arab Emirates. ${ }^{45}$ Some of the attachés are covering more than one country. They inform nationals abroad about their rights at work or social security benefits (family allowance, unemployment allowance, pension, etc.) in the country of residence. As observed in Italy, attachés also contact local authorities if the labor and social security rights of Romanian citizens are not respected. They can also request information about the Romanian nationals' situation to make sure their rights are respected. ${ }^{46}$

In terms of consular services, every diplomatic mission and/or consular section is obliged to publish on their website the prerogatives of the consular officers. Consular services are clearly mentioned and are limited to the following: issuance of identity and travel documents; obtaining documents from Romania (birth, marriage, death certificates, criminal records certificate, work books, certificates attesting the years of work carried out in Romania); registration of civil status documents issued by foreign authorities; notary acts; Romanian citizenship; marriage at the embassy. ${ }^{47}$

According to Law No. 198/2008 on payable consular services and the handling fees levied at the diplomatic missions and consular posts of Romania abroad, the Ministry of Foreign Affairs is able to make full use of the supplementary fees for expedited administrative services to respond to the following situations: payment of transportation costs for Romanian citizens in special situations and without financial resources, support to children without a legal tutor, including transportation payment, accommodation and daily allowance expenditures for the persons accompanying them when assisted repatriation is required. ${ }^{48}$ Nevertheless, following the 2017 legislative amendment, the consular fees were eliminated almost entirely and, consequently, the extra fees for consular services provided in a fast-track manner

\footnotetext{
${ }^{44}$ Ministry of Labor and Social Justice General - Directorate for European Affairs and International Relations. Frequently Asked Questions. https://bit.ly/2GRmzB4. Accessed March 2019.

${ }^{45}$ Ministry of Labor and Social Justice. The list of attachés on labor and social problems within Romania's diplomatic missions. https://bit.ly/2HyfN4E. Accessed March 2019.

${ }^{46}$ Ministry of Labor and Social Justice and the Romanian Embassy in Italy, the Office of the Attaché on labor and social problems. The Romanian Worker's Guide in Italy. https://bit.ly/2GTriqf. Accessed March 2019.

${ }^{47}$ Articles 15-21 Government Decision No. 760/1999 on Consular Regulation; Romanian Embassy in Hungary, Consular services for Romanian citizens, available at: https://bit.ly/2qrU0TN [accessed March 2019].

${ }^{48}$ Article 15 (1) (a) Law No.198/2008 on charged consular services and the handling fees levied at the diplomatic missions and consular posts of Romania abroad.
} 
are almost inexistent. ${ }^{49}$ These payments are now mostly covered from the state budget. In practice, repatriation costs are covered by the consular offices or embassies, only in exceptional cases, and require prior ministerial approval.

As a rule, the costs of repatriation of corpses to Romania are borne by the family of the deceased unless they are privately insured. Romanian diplomatic missions or consular offices may pay for the repatriation of bodies only if the family cannot bear such costs and there is no possibility of burial in the state where the death occurred..$^{50}$ The costs set out by Article 15 para. (1) of Law No. 198/2008 are not reimbursable. If the beneficiaries voluntarily refund the costs covered by the consulates, the amount will go to the consular office's own revenues..$^{51}$

The Romanian law does not contain any provision on the obligation of consulates to provide in-cash or in-kind benefits to nationals residing abroad in case of non-health related economic hardship, unemployment, or social benefits for families upon birth of a child abroad and/or to raise children abroad. Nevertheless, in the emergency case of the earthquake that occurred in Italy in 2016, the Romanian Government granted additional financial aid to Romanian citizens, complementary to that already granted by the Italian Government. ${ }^{52}$

\subsubsection{Unemployment}

Next to EU regulations regarding the access to unemployment benefits of Romanians residing in another Member State, ${ }^{53}$ the Romanian law on unemployment benefits does not include provisions regarding Romanians abroad. However, it stipulates that Romanians working abroad may voluntarily contribute to the unemployment insurance system in Romania, only if they are at least 18 years old, they have their domicile or residence in Romania and they are insured under the public pension and health scheme. ${ }^{54}$

\footnotetext{
${ }^{49}$ Article IX of the Law No. 1/2017 on the elimination of certain taxes and fees, as well as for the amendment and completion of some legislative acts, published in the Official Gazette no 15 of 6January 2017.

${ }^{50}$ Article 15 (1) (b) Law No.198/2008 on charged consular services and the handling fees levied at the diplomatic missions and consular posts of Romania abroad.

${ }^{51}$ Article 21(7) of the Order 400/2016 on the technical modalities for the provision of consular services and the control of the revenue from these services at the diplomatic missions and consular offices of Romania abroad.

${ }^{52}$ Romanian Embassy in Italy, Emergency aid for the Romanians affected by the earthquake in Italy, available at: https://bit.ly/2HhvAai [accessed March 2019].

${ }^{53}$ Articles 61-65 Regulation (EC) No 883/2004 of the European Parliament and of the Council of 29 April 2004 on the coordination of social security systems (Text with relevance for the EEA and for Switzerland).

${ }^{54}$ Articles 20(1) (e) and 22 Law 76 of 16 January 2002 on the unemployment benefit system and on the stimulation of employment.
} 
Consulates do not provide cash benefits to nationals residing abroad who find themselves in situation of unemployment. However, if a Romanian citizen living abroad qualifies for unemployment benefits in the host country, but for various reasons he/she does not receive them and his/her social rights are infringed, the Consulate or the attaché may then intervene. Official steps may be taken in this regard by the consular officers by way of inter alia, enquiring about the Romanian national's situation with the authorities of the residence country or recommend an attorney. If the national does not know exactly the legal procedures, he/she may be informed by the consulate (National Strategy 2017-2020).

The Vienna Convention on Consular Relations provides that one of the consular functions is the provision of help and assistance to nationals, ${ }^{55}$ which may be interpreted as potentially including also the provision of assistance for job search. However, the Romanian Consular Regulation stipulates in which cases consulates may provide assistance and protection to nationals, and assistance with searching a job is not among the services included. Furthermore, it is specifically mentioned in the consular assistance leaflet drafted by the Ministry of Foreign Affairs ${ }^{56}$ and on the embassies' websites, that the consular officer may not assist a national in his/her job search in the host country. In other words, assistance for searching a job is not considered a consular service. ${ }^{57}$ Similarly, unemployment is not considered a cause for benefiting from the repatriation policy set out in Article 15(1) (b) of Law No. 198/2008.

In spite of these limitations, information related to unemployment situations is provided to Romanians abroad through the Romanian Worker's Guide. This document was developed jointly by the Ministry of Foreign Affairs and the office of the attaché on labor and social problems from the Ministry of Labor and Social Justice. The guide may be accessed on the embassies' websites ${ }^{58}$ In addition to this general information, there is sometimes also information of interest available within the particular web section dedicated to a foreign country. For example, a guide on Useful information for domestic and care staff ("colf/badante") is available in Italy, as many Romanians were/are working in this field. ${ }^{59}$

\footnotetext{
${ }^{55}$ Article 5(e) of the Vienna Convention on Consular Relations signed on 24 April 1963, entered into force on 19 March 1967, UN Treaty Series, vol. 596, p. 261.

${ }^{56}$ Ministry of Foreign Affairs (2018). Leaflet. https://bit.ly/2qpRG0B. Accessed March 2019.

${ }^{57}$ Romanian Embassy in Hungary. What embassy representatives cannot do for you, https://bit. ly/2GT9nzY. Accessed March 2019.

${ }^{58}$ See: The Romanian Worker's Guide in Germany. https://bit.ly/2IJmn7F. Accessed March 2019. The Romanian Worker's Guide in Spain. https://bit.ly/2HhpGG4. Accessed March 2019.

${ }^{59}$ Office of the Attaché on labor and social problems. Useful information for domestic and care staff ("colf / badante") in Italy. https://bit.ly/2IOqS0K. Accessed March 2019.
} 


\subsubsection{Health Care}

According to Law No. 227/2015 on the Fiscal Code, ${ }^{60}$ only Romanians with the domicile or residence in Romania have the status of taxpayers. This means that they contribute to the social health insurance system, in accordance with the provisions of the EU legislation applicable in the field of social security, and the relevant social security systems agreements to which Romania is a party, as the case may be. Consequently, Romanians living abroad cannot be covered by the Romanian health insurance. Nevertheless, if the person worked also in Romania and he/she applies for invalidity pension in the country of residence (where he/she also worked), he/ she is entitled to an invalidity pension from both countries.

In the EU, the country responsible for a person's social security and health insurance depends on his/her economic status and his/her place of residence - not his/her nationality. However, the Romanian Fiscal Code foresees the possibility to contribute to the health insurance system for individuals without income who do not fall into the categories of persons exempted from the payment of the social health insurance. ${ }^{61}$ The respective person owes the social health insurance contribution for 12 months, which equals to six gross national salaries, regardless of the date of filing in the declaration. ${ }^{62}$ In exchange, the citizen benefits of the same health insurance services as resident nationals. ${ }^{63}$

According to Article 153 of the Fiscal Code, Romanian citizens domiciled or residing in Romania have the status of taxpayers to the social health insurance system, in compliance with the provisions of the EU legislation applicable in the field of social security, as well as of the social security agreements signed by Romania. Consequently, the possibility to pay the health insurance also applies to Romanians abroad, which maintained their domicile in Romania.

In addition, consular assistance and protection is granted in case of serious illness, medical emergencies, deaths, traffic accidents, and arrest or detention by consular service, on request or ex officio. ${ }^{64}$ Concerning repatriation in case of health issues, there are no specific policies according to which consulates offer repatriation services to nationals residing abroad who encountered economic hardship. Thus, the general rules apply also to these situations. ${ }^{65}$

\footnotetext{
${ }^{60}$ Article 153 (1)a)Law No. 227/2015 on the Fiscal Code, published in the Official Gazette no 688 of 10 September 2015.

${ }^{61}$ Article 180(1)b) Fiscal Code.

${ }^{62}$ Article 180(3) Fiscal Code.

${ }^{63} \mathrm{See}$ the wesbite of the national health insurance authority as http://www.cnas.ro/page/drepturilesi-obligatiile-asiguratilor.html [accessed March 2019].

${ }^{64}$ Article 14(1) and (2) of the Government Decision on Consular Regulation.

${ }^{65}$ Article 15 Law No.198/2008 on charged consular services and the handling fees levied at the diplomatic missions and consular posts of Romania abroad.
} 


\subsubsection{Pensions}

In the area of pension, Romania's engagement towards nationals abroad is limited to enabling pension exportability for individuals who have worked in the country. Regulation (EEC) No. 1408/71 and Law No. 19/2000 provide the relevant standards governing the transfer procedures for pension benefits. To receive the payment of benefits abroad, the beneficiary of the Romanian pension and other social security rights has to communicate to the regional retirement fund authority the information regarding the account opened abroad where the benefits will be paid and to complete and transmit the Life Certificate, as instructed by the retirement fund authority. In the case of beneficiaries living abroad, the document including the bank details shall be accompanied by a proof of their residence. The declaration may be sent by post or e-mail. Non-resident beneficiaries are obliged to submit a Life Certificate annually by 31st of December of each year. A legal authority of the host country has to certify that the Life Certificate was signed by the beneficiary. The legal authority may also be a diplomatic mission or consular office of Romania in the state of residence. ${ }^{66}$ The retirement fund authority and its regional offices are competent to receive and assess the requests for pension transferability. The attachés on labor and social problems appointed by the Ministry of Labor and Social Justice may also provide information on the pension schemes, which exist in the countries where the attachés are present.

\subsubsection{Family-Related Benefits}

Romania has no policies regarding birth grants neither for nationals living in Romania, nor for those abroad. However, in 2017, the General Council of the Bucharest Municipality adopted a decision on granting a financial incentive to parents of a child born in Bucharest. ${ }^{67}$

The National Agency for Payments and Social Inspection (ANPIS) is the central institution that manages the payment of all benefits of social assistance and has inter alia the following tasks: ensures correspondence with Member States through European forms on social assistance benefits for child and family support; informs interested parties about the rights to social assistance benefits for children and family support based on EU regulations; elaborates responses to petitions addressed by natural or legal persons, from the country or abroad, regarding the criteria for entitlement to social assistance benefits for the support of the child and the family in Romania, according to the provisions of Regulation No. 883/2004.

\footnotetext{
${ }^{66}$ Romanian Embassy in Italy. Pension transfer and life certificate. https://bit.ly/2vbqpDU. Accessed March 2019.

${ }^{67}$ General Directorate for Social Assistance Bucharest, Financial incentive for new-born children, https://bit.ly/2v8b6fb [accessed March 2019].
} 
Following widespread concerns over the number of children left behind by parents who emigrated, the Romanian authorities enacted special provisions in order to protect children in these situations. ${ }^{68}$ According to the Child Protection Act, ${ }^{69}$ a parent who exercises the parental authority alone and who is about to go to work abroad has the obligation to notify this intention to the public social service at home, at least 40 days before leaving the country. The notification shall include the person designated to take care of the child during the absence of the parents or the guardian. The guardianship court has to confirm the person who will be in charge of taking care of the child left behind. Several conditions have to be fulfilled by the designated person. The law also prescribes a monitoring procedure on how the child whose parents went abroad to work is raised and cared for.

\subsubsection{Economic Hardship}

The guaranteed minimum income scheme foreseen by Law No. 416/2001 on Guaranteed Minimum Income is not accessible to Romanians living abroad. Beneficiaries of this scheme are Romanian citizens and foreigners with domicile or residence in Romania and homeless persons. ${ }^{70}$ The monthly minimum guaranteed income is determined based on the social reference indicator (indicator social de referinta, ISR) set by the law. ${ }^{71}$ The guaranteed minimum income cannot be transferred abroad since the persons who are benefiting from it have certain obligations requiring their presence in Romania. ${ }^{72}$

Concerning financial help for those facing economic hardship, there are no specific policies according to which consulates offer financial help to Romanians living abroad in this situation beyond the intervention of consular assistance in the exceptional circumstances mentioned above. The guaranteed minimum income cannot be transferred abroad since the persons who are benefiting from it have certain obligations, which require their presence in Romania, more exactly in the municipality where they requested social assistance. Thus, one or more family members are obliged to do community work aiming at social integration. ${ }^{73}$

\footnotetext{
${ }^{68}$ The precise number of the children left behind by Romanian parents is subject to debate. While media publication reports approximately 300,000 children in such a situation (http://bonafides.be/ romanians-abroad-a-diaspora-in-conflict-with-itself/), Save the Children Romania cited data collected by the National Authority for Children Protection, which was of 94,700 in 2018, on the rise from 85,000 in 2015 . However, the later data might not reflect the reality; the actual number might be higher, since most parents do not report to the National Authority for fear of repercussions.

${ }^{69}$ Articles $104-108$ of the Law No. 272 of 2004 on the Child Protection Act.

${ }^{70}$ Articles 1(1), 2(7) and 3(2) Law No.416/2001.

${ }^{71}$ More details are set out in Law No. 76 of 16 January 2002 on the unemployment benefit system and on the stimulation of employment.

${ }^{72}$ Articles 6, 14(1), 15(7) Law No.416/2001.

${ }^{73}$ Article 6 Law No.416/2001.
} 
In addition to the guaranteed minimum income, the law also prescribes other forms of social assistance, such as: the social protection measures during the cold season ${ }^{74}$ and family allowance. ${ }^{75}$ These benefits are also not accessible to nationals residing abroad.

\subsection{Conclusions}

The legal and policy framework regarding consular assistance of Romanians abroad has substantially improved since 2016, influenced perhaps by the rising number of Romanians living abroad and their potential influence in national elections. ${ }^{76}$ The institutional setting has expanded in terms of both specialized bodies and total number of consular officials, with the stated aims of maintaining and promoting national identity, promoting diaspora associations, and aiding with the integration process of Romanians in their new host communities. The elimination of emergency consular taxes or the increase of financial support allocated to Romanians during the earthquake in Italy were additional steps taken by the Romanian Government to respond to the needs of the diaspora.

In addition to offering increased institutional and financial support to Romanians abroad, efforts have been made to attract emigrants' return back to Romania. Examples in this regard are the financial help to start-up businesses for those wishing to return to Romania or the reintegration support via the specialized programme InvestRomania. One might find these external and internal measures as reflecting a positive development of the Romanian institutional and policy setting dedicated to its diaspora. The main drawback of the policy agenda for Romanians abroad is the lack of empirical evidence to support the choice of these prioritised objectives and their substantiation in policy instruments. It is not evident why those particular objectives were chosen and not others, in absence of a well informed impact assessment or study assessing the needs of the Romanian diaspora preceding the adoption of the national strategy. Therefore, it is debatable that they actually reflect the needs and wishes of Romanians abroad (Martinescu and Burlacu 2019).

In conclusion, it is worth mentioning perhaps the biggest challenge faced by diaspora issues, that is their politicisation. This phenomenon made diaspora associations financially dependent on public funding - an allocation that has been argued to lack transparency (Martinescu and Burlacu 2019), and led to a persistent political misrepresentation of the diaspora in the Parliament. Given the recent reform of the institutional and policy setting on diaspora, it remains to be seen how it will unfold in practice. In particular, whether they will achieve the stated aims and develop into a consistent, coherent and efficient apparatus, given the challenge of proliferation of specialized institutional bodies.

\footnotetext{
${ }^{74}$ Emergency Ordinance No. 70/2011 on Social Protection Measures during the Cold Season.

${ }^{75}$ Law No. 277/2010.

${ }^{76}$ Triculescu, R. The Romanian Diaspora as an Unlikely Opposition. https://chargedaffairs.org/ romanian-diaspora-opposition/. Accessed March 2019.
} 
Acknowledgements This chapter is part of the project "Migration and Transnational Social Protection in (Post)Crisis Europe (MiTSoPro)" that has received funding from the European Research Council (ERC) under the European Union's Horizon 2020 research and innovation programme (Grant agreement No. 680014). In addition to this chapter, readers can find a series of indicators comparing national social protection and diaspora policies across 40 countries on the following website: http://labos.ulg.ac.be/socialprotection/.

\section{References}

Anghel, R., Botezat, A., Cosciug, A., et al. (2016). International migration, return migration, and their effects: A comprehensive review on the Romanian case. IZA Discussion Papers No 10445, Institute for the Study of Labor (IZA), 1.

Burlacu, I., Soare, S., \& Vintila, D. (2020). Migrants' access to social protection in Romania. In J.-M. Lafleur \& D. Vintila (Eds.), Migration and social protection in Europe and beyond (volume 1): Comparing access to welfare entitlements. Cham: Springer.

Eurostat (2018). Migration and migrant population statistics, 3. https://bit.ly/2DuBGjq. Accessed March 2019.

Jiglău, G. (2016). Legea electorală îi descurajează pe românii din străinătate să voteze 9 December 20. https://bit.ly/2YmYmvH. Accessed March 2019.

Martinescu, A., \& Burlacu, R. (2019). Understanding the Romanian diaspora. The Foreign Policy Centre. https://fpc.org.uk/understanding-the-romanian-diaspora/. Accessed March 2019.

Ministry of Foreign Affairs (2018). Leaflet. https://bit.ly/2qpRG0B. Accessed March 2019.

Moraru, M. (2010). Chapter on Romania. Citizens Consular Assistance Regulation in Europe (CARE) Final Report, pp. 393-424. http://www.careproject.eu/images/stories/ ConsularAndDiplomaticProtection.pdf. Accessed March 2019.

Prisăcaru, M. (2017). "Noi vrem congres!" - Scrisoare deschisă a Consiliului Românilor de Pretutindeni, https://www.stiripesurse.ro/noi-vrem-congres-scrisoare-deschisa-a-consiliuluiromanilor-de-pretutindeni_1237679.html. Accessed March 2019.

Sandu, D. (2010). Lumile sociale ale migrației româneşti în străinătate. Iaşi: Polirom Publishing House.

United Nations (2015). International Migration Report 2015 Highlights, 19. https://bit.ly/1RQIond. Accessed March 2019.

USR (2018). Poziţia USR pe tema Congresului Românilor de Pretutindeni. https://www.usr. ro/2018/01/31/pozitia-usr-pe-tema-congresului-romanilor-de-pretutindeni/. Accessed March 2019.

Vintila, D., \& Soare, S. (2018). Report on political participation of Mobile EU citizens: Romania. RSCAS/GLOBALCIT-PP 2018/10. https://bit.ly/2FiuFTR. Accessed March 2019.

Open Access This chapter is licensed under the terms of the Creative Commons Attribution 4.0 International License (http://creativecommons.org/licenses/by/4.0/), which permits use, sharing, adaptation, distribution and reproduction in any medium or format, as long as you give appropriate credit to the original author(s) and the source, provide a link to the Creative Commons license and indicate if changes were made.

The images or other third party material in this chapter are included in the chapter's Creative Commons license, unless indicated otherwise in a credit line to the material. If material is not included in the chapter's Creative Commons license and your intended use is not permitted by statutory regulation or exceeds the permitted use, you will need to obtain permission directly from the copyright holder. 